\title{
PHARMACOGNOSY AND NEW TRENDS OF B. PHARM SYLLABI
}

\section{Original Article}

\author{
I. M. ABU-AL-FUTUH SHANDAL, SUMIA S. MOHAMED, MOUSA A. QARAWI*
}

College of Pharmacy and Health Sciences, Ajman University, Fujairah Campus, Fujairah City, P. O. Box. 2202 UAE

Email: mqarawi@yahoo.co.uk

Received: 11 Jul 2018, Revised and Accepted: 07 Sep 2018

\begin{abstract}
Objective: The Pharmacy profession has evolved from its conventional drug focused basis to an advanced patient focused basis over the years. Accordingly, many universities worldwide are modifying their Curricula in order to reflect this change.

Methods: This paper investigates and compares the syllabi of B. Pharm for different Universities in Africa and Asia. Pharmacy Syllabi of the included Universities is presented in the form of Sectors, i.e. Pharmaceutical Sciences, Clinical Pharmacy, Biomedical, Training and University Requirements. Percentage analysis of credit hours allotted to courses of each Sector performed with special emphasis on courses of Pharmacognosy and Pharmaceutical Science in comparison to courses of Clinical Pharmacy.
\end{abstract}

There is a substantial decrease in teaching hours of Pharmaceutical Sciences, particularly Pharmacognosy within the B. Pharm Curricula of some of the included Universities at the expense of including more courses in Clinical Pharmacy.

Results: Pharmacists are scientists as well as clinicians, and basic science knowledge such as pharmaceutical sciences, give pharmacy graduates critical scientific foundations, in this regard, the reduction in pharmaceutical sciences content in a pharmacy curriculum may compromise the competence of pharmacy graduates, as the drug experts from the basic science level to the clinical level.

Conclusion: The impact of reducing pharmaceutical science content, may compromise the Pharmacist ability to assume certain duties in the countries included in the study. This in consideration that Clinical Pharmacy is not widely practiced in the investigated countries and its application is limited compared to other job opportunities available for Pharmacy graduates of these countries such as Community Pharmacy, Pharmaceutical Industries, marketing and sales and utilization of natural resources of medicinal plants by research and development units.

Recommendations on how to avoid such decrease in teaching hours of Pharmaceutical Courses and fulfil the job requirements in the above countries are given.

Keywords: Pharmacy profession, New trend Pharmacognosy.

(c) 2018 The Authors. Published by Innovare Academic Sciences Pvt Ltd. This is an open access article under the CC BY license (http://creativecommons.org/licenses/by/4.0/] DOI: http://dx.doi.org/10.22159/ijcpr.2018v10i6.30970

\section{INTRODUCTION}

Although, Clinical Pharmacy is well recognized in developed countries, its implementation is still at nascent stage in developing countries [1]. The profession of Pharmacy in developing countries is geared more into Community pharmacy and the Pharmaceutical Industry, i.e. it is still product oriented rather than patient focused practice. Moreover, the role of clinical pharmacist is still unclear among health authorities and the community $[2,3]$.

Advancements in the field of pharmaceutical sciences and progressing role of pharmacist in direct patient care are compelling pharmacy institutions to come up with new courses oriented towards patient care [4]. The introduction of Clinical Pharmacy has necessitated a change in the current curriculum of pharmacy education in developing countries [5].

During the last few years, the worldwide move towards placing more emphasis on Clinical Pharmacy has resulted in substantial expansion of Clinical pharmacy courses in B. Pharm Syllabi while there was associated trend of diminishing Pharmaceutical Sciences Courses, especially Pharmacognosy. This is mainly due to increasing application of Clinical Pharmacy in Developed Countries.

Basic science content must be maintained in pharmacy curricula if the profession is to survive because basic science content is foundational for the understanding of human disease and associated drug therapies [6]. The basic science in Pharmacy curriculum gives students a sound foundation on which to develop the skills necessary for patient-centered pharmaceutical care [7]

Recently, moves to increase emphasis on clinical work have extended to some Developing Countries without considering the extent of its application, the readiness of Pharmacy Practice and the national needs of these countries. In South Asian and Southeast Asian countries, it has been reported that there is a deficiency of an ideal clinical pharmacy setup in health care system [8].

It seems controversial why there was a need for PharmD program in many developing countries; the adoption of PharmD program in developing countries was either based on true needs or it was just started to fulfil the needs of international standards [9].

The curriculum of the American universities and periodic updates by the Accreditation Council of Pharmacy Education (ACPE) are the main source of inspiration for such countries. Often it is seen that curriculum is updated, revised or some time copied from these resources. This practice gives rise to many questions such as whether or not this course fulfils the specific national needs of the countries involved, whether there are enough facilities in the local institutions and health care authorities, which allow the students to practice what they have learned theoretically [8].

\section{MATERIALS AND METHODS}

\section{Data collection}

Data is collected by Internet using Google Search through the Key Words: Pharmacy Study Plan, Pharmacy Syllabi, Universities, Africa, Asia, Pharmacognosy, Clinical Pharmacy [10-25].

\section{Data analysis}

The Credit hours structures of B. Pharm Programs for the included Universities in Developing Countries is classified into 4 main sectors: 1-Pharmaceutical Sciences; 2-Clinical Pharmacy; 3Biomedical sciences and 4-University Requirements. 
The Pharmaceutical Sciences include the basic subjects of Pharmacy, i.e. Courses in Pharmaceutics, Pharmacognosy, Pharmacology and Pharmaceutical Chemistry.

Clinical Pharmacy include courses and training such as: Clinical Pharmacy, Clinical Nutrition, Pharmacy Practice, Hospital Training, Community Training, OTC Drugs (Non-Prescription), Patient Assessment and Pharmaceutical Care, Legislation, Pharmacy Law, Pharmacoepidimeology, Pharmacoethics, Pharmacoeconomics, Pharmacy Management and Marketing. The Biomedical Sector includes Anatomy and Physiology, Biochemistry, Microbiology, Pathology and Biotechnology.

University Requirements include Arabic and English Languages, Islamic studies, Social and Psychological studies, Computer Application, Statistics, Art, Innovation and Research and others.
Descriptive analysis for data on the above four Sectors was performed.

\section{RESULTS}

Table 1 illustrates a comparative distribution for credit hour structures of B. Pharm Programs between Universities in UAE. The total B. Pharm. Credit hours range between 145-170 credit hours, with an average of 158 credit hours instructed within $4 \mathrm{y}$. This includes theoretical and practical teaching as well as training. The credit hours allotted to Clinical Pharmacy in these Universities range between 26-50 credit hours with an average of $24 \%$ of the total B. Pharmcredit hours. This is relatively high as compared to total subjects of all Pharmaceutical Sciences (Pharmaceutics, Pharmacognosy, Pharm, Chemistry and Pharmacology) which range between $68-81$ credit hours with an average of $48 \%$ of the total B Pharm. credit hours. Pharmacognosy credit hours are relatively low (3-11 h) with an average of $4 \%$ of the Total B. Pharm. Credit hours.

Table 1: Credit hour structures of B. Pharm programs for UAE universities

\begin{tabular}{|c|c|c|c|c|c|c|}
\hline $\begin{array}{l}\text { S. } \\
\text { No. }\end{array}$ & University & $\begin{array}{l}\text { Total credit } \\
\text { hours }\end{array}$ & $\begin{array}{l}\text { Pharmaceutical } \\
\text { sciences }\end{array}$ & $\begin{array}{l}\text { Clinical } \\
\text { pharmacy }\end{array}$ & $\begin{array}{l}\text { Bio- } \\
\text { medical }\end{array}$ & $\begin{array}{l}\text { University } \\
\text { requirements }\end{array}$ \\
\hline 1 & Ajman University (Current)(10) & 150 & $\begin{array}{l}81(54 \%) \\
* \operatorname{Cog} 11(7.3 \%)\end{array}$ & $26(17.5 \%)$ & $19(12.5 \%)$ & $24(16 \%)$ \\
\hline 2 & Ajman University (Proposed) & 160 & $\begin{array}{l}74(46 \%) \\
\operatorname{Cog} 06(3.6 \%)\end{array}$ & $39(24.5 \%)$ & $23(14.5 \%)$ & $24(15 \%)$ \\
\hline 3 & $\begin{array}{l}\text { Al-Ain University of Science and } \\
\text { Technol.(11) }\end{array}$ & 160 & $\begin{array}{l}69(43 \%) \\
\operatorname{Cog} 05(3.1 \%)\end{array}$ & $43(27 \%)$ & $15(9.5 \%)$ & $33(20.5 \%)$ \\
\hline 4 & University of Sharjah(12) & 170 & $\begin{array}{l}68(40 \%) \\
\operatorname{Cog} 04(2.4 \%)\end{array}$ & $50(29.5 \%)$ & $19(11 \%)$ & $33(19.5 \%)$ \\
\hline 5 & Dubai Pharmacy College(13) & 164 & $\begin{array}{l}79(48 \%) \\
\operatorname{Cog} 09(5.5 \%)\end{array}$ & $46(28 \%)$ & $21(13 \%)$ & $18(11 \%)$ \\
\hline 6 & $\begin{array}{l}\text { RAK Medical and Health Sciences } \\
\text { University(14) }\end{array}$ & 145 & $\begin{array}{l}79(54.5 \%) \\
\operatorname{Cog} 03(2.1 \%)\end{array}$ & $28(19.5 \%)$ & $17(11.5 \%)$ & $21(14.5 \%)$ \\
\hline & Average & 158 & $48 \% * * \operatorname{Cog} 4 \%$ & $24 \%$ & $12 \%$ & $16 \%$ \\
\hline
\end{tabular}

*Cog: Refers to courses of Pharmacognosy.**Pharmacognosy Percentage calculated from Total Credit Hours.

The profile of the comparative distribution for credit hour structures of B. Pharm Programs between other Gulf Universities shown in table 2 is nearly the same as that in table 1 . In these Universities, credit hours allocated to Pharmacognosy are even less than Universities in the UAE. It ranges between $0-5$ credit hours with an average of $2 \%$ from the total B. Pharm credit hours. The expression "Natural Products" used in above Universities for courses of Pharmacognosy.

However the percentage of credit hours allocated to clinical pharmacy is relatively lower than the UAE universities, i.e. $18 \%$

Table 2: Credit hour structures of B. Pharm programs for other gulf universities

\begin{tabular}{|c|c|c|c|c|c|c|}
\hline $\begin{array}{l}\text { S. } \\
\text { No. }\end{array}$ & University & $\begin{array}{l}\text { Total credit } \\
\text { hours }\end{array}$ & $\begin{array}{l}\text { Pharmaceutical } \\
\text { sciences }\end{array}$ & $\begin{array}{l}\text { Clinical } \\
\text { pharmacy }\end{array}$ & $\begin{array}{l}\text { Bio- } \\
\text { medical }\end{array}$ & $\begin{array}{l}\text { University } \\
\text { requirements }\end{array}$ \\
\hline 1 & $\begin{array}{l}\text { Almaarefa College (Kingdom of Saudi } \\
\text { Arabia)(15) }\end{array}$ & 171 & $\begin{array}{l}75(43.9 \%) \\
{ }^{*} \operatorname{Cog} 05(2.9 \%)\end{array}$ & $32(18.7 \%)$ & $32(18.7 \%)$ & $32(18.7 \%)$ \\
\hline 2 & Kuwait University(16) & 154 & $\begin{array}{l}75(48.7 \%) \\
\operatorname{Cog} 00(0 \%)\end{array}$ & $30(19.5 \%)$ & $24(15.6 \%)$ & $25(16.2 \%)$ \\
\hline 3 & Al-Bahrain University(17) & 143 & $\begin{array}{l}77(53.8 \%) \\
\operatorname{Cog} 03(2.1 \%)\end{array}$ & $23(16.1 \%)$ & $19(13.3 \%)$ & $24(16.7 \%)$ \\
\hline 4 & Qatar University(18) & 173 & $\begin{array}{l}71(41.8 \%) \\
\operatorname{Cog} 02(1.2 \%)\end{array}$ & $47(27.2 \%)$ & $22(12.7 \%)$ & $33(19.1 \%)$ \\
\hline 5 & $\begin{array}{l}\text { Lebanese International University } \\
\text { (Yemen)(19) }\end{array}$ & 173 & $\begin{array}{l}94(54.3 \%) \\
\operatorname{Cog} 03(1.7 \%)\end{array}$ & $31(18 \%)$ & $21(12.1 \%)$ & $27(15.6 \%)$ \\
\hline & Average & 162 & $49 \% * * \operatorname{Cog} 2.1 \%$ & $18 \%$ & $16 \%$ & $17 \%$ \\
\hline
\end{tabular}

Table 3 illustrates a comparative distribution for credit hour structures of B. Pharm Programs between Universities from Africa. The average total credit hours for the B. Pharm is 191 credit hours instructed within 5-6 y. In these Universities, an even balance is maintained between all Pharmacy subjects. Clinical Pharmacy has an average of $13.5 \%$ in the total credit hours, the other four Pharmacy subjects have a combined share of $57 \%$. The Pharmacognosy subject has comparatively reasonable percentage of the credit hours $(10 \%)$.

Table 3: Credit hour structures of B. Pharm programs for universities in africa

\begin{tabular}{|c|c|c|c|c|c|c|}
\hline S. No. & University & $\begin{array}{l}\text { Total credit } \\
\text { hours }\end{array}$ & Pharmaceutical sciences & Clinical pharmacy & Bio-medical & $\begin{array}{l}\text { University } \\
\text { requirements }\end{array}$ \\
\hline 1 & $\begin{array}{l}\text { University of Khartoum } \\
\text { (Proposed) (20) }\end{array}$ & 190 & $\begin{array}{l}118(62 \%) \\
* \operatorname{Cog} 19(10 \%)\end{array}$ & $18(9.5 \%)$ & $32(17 \%)$ & $22(11.5 \%)$ \\
\hline 2 & Cairo University (21) & 192 & $104(54 \%) \operatorname{Cog} 21(11 \%)$ & $38(20 \%)$ & $39(20 \%)$ & $11(6 \%)$ \\
\hline 3 & $\begin{array}{l}\text { University of Nigeria (22) } \\
\text { Average }\end{array}$ & $\begin{array}{l}192 \\
191\end{array}$ & $\begin{array}{l}104(54 \%) \operatorname{Cog} 17(9 \%) \\
57 \%{ }^{* *} \operatorname{Cog} 10 \%\end{array}$ & $\begin{array}{l}21(11 \%) \\
13.5 \%\end{array}$ & $\begin{array}{l}28(15 \%) \\
17 \%\end{array}$ & $\begin{array}{l}38(20 \%) \\
12.5 \%\end{array}$ \\
\hline
\end{tabular}


Table 4 shows a comparative distribution for credit hour structures of B. Pharm Programs between some Universities from Asia. The B. Pharm, total credit hours in these Universities are relatively higher with an average of 215 credit hours instructed within 5 y. A moderate distribution of Pharmacy subjects nearly maintained (Clinical Pharmacy 16\%; total 4 Pharmaceutical Science subjects $52 \%$ of which Pharmacognosyis $6.7 \%)$.

Table 4: Credit hour structures of B. Pharm programs for other universities from Asia

\begin{tabular}{|c|c|c|c|c|c|c|}
\hline $\begin{array}{l}\text { S. } \\
\text { No. }\end{array}$ & University & $\begin{array}{l}\text { Total credit } \\
\text { hours }\end{array}$ & $\begin{array}{l}\text { Pharmaceutical } \\
\text { sciences }\end{array}$ & $\begin{array}{l}\text { Clinical } \\
\text { pharmacy }\end{array}$ & $\begin{array}{l}\text { Bio- } \\
\text { medical }\end{array}$ & $\begin{array}{l}\text { University } \\
\text { requirements }\end{array}$ \\
\hline 1 & Near East University (Turkey))(23) & 215 & $\begin{array}{l}115(53.5 \%) \\
* \operatorname{Cog} 15(7.0 \%)\end{array}$ & $53(24.6 \%)$ & $\begin{array}{l}25(11.6 \\
\%)\end{array}$ & $22(10.3 \%)$ \\
\hline 2 & Al-Baath University (Syria)(24) & 265 & $\begin{array}{l}136(51.5 \%) \\
\operatorname{Cog} 23(9.0 \%)\end{array}$ & $20(7.5 \%)$ & $58(22 \%)$ & $51(19 \%)$ \\
\hline 3 & $\begin{array}{l}\text { Jordon University of Science and } \\
\text { Technology(25) }\end{array}$ & 165 & $\begin{array}{l}84(51 \%) \\
\operatorname{Cog} 07(4.3 \%)\end{array}$ & $29(17 \%)$ & $\begin{array}{l}27(16.5 \\
\%)\end{array}$ & $25(15.5 \%)$ \\
\hline & Average & 215 & $52 \%{ }^{* *} \operatorname{Cog} 6.7 \%$ & $16 \%$ & $17 \%$ & $15 \%$ \\
\hline
\end{tabular}

Fig. 1 indicates that in UAE Universities, the credit hours allotted to Clinical Pharmacy subject are relatively high as compared to the total four subjects of Pharmaceutical Sciences. Whereas, in other Gulf Universities, it is relatively moderate. In Asian and African
Universities, credit hours allotted to Clinical Pharmacy are in even balance with the total four subjects of Pharmaceutical Sciences. Biomedical and University Requirements are nearly similar in all universities.

\section{A-UAE Universities}

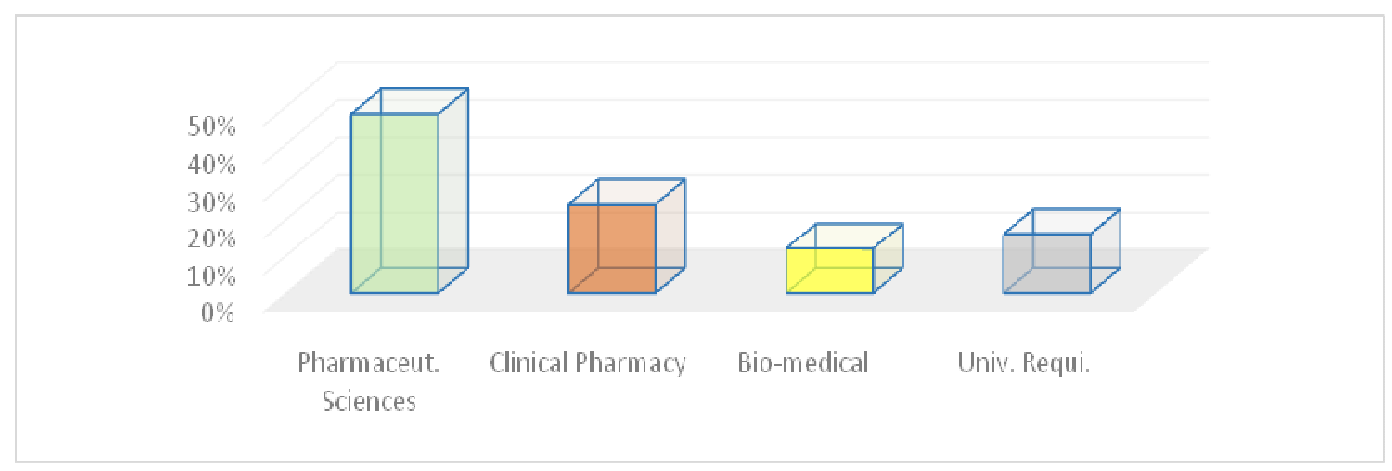

B-Other Gulf Universities

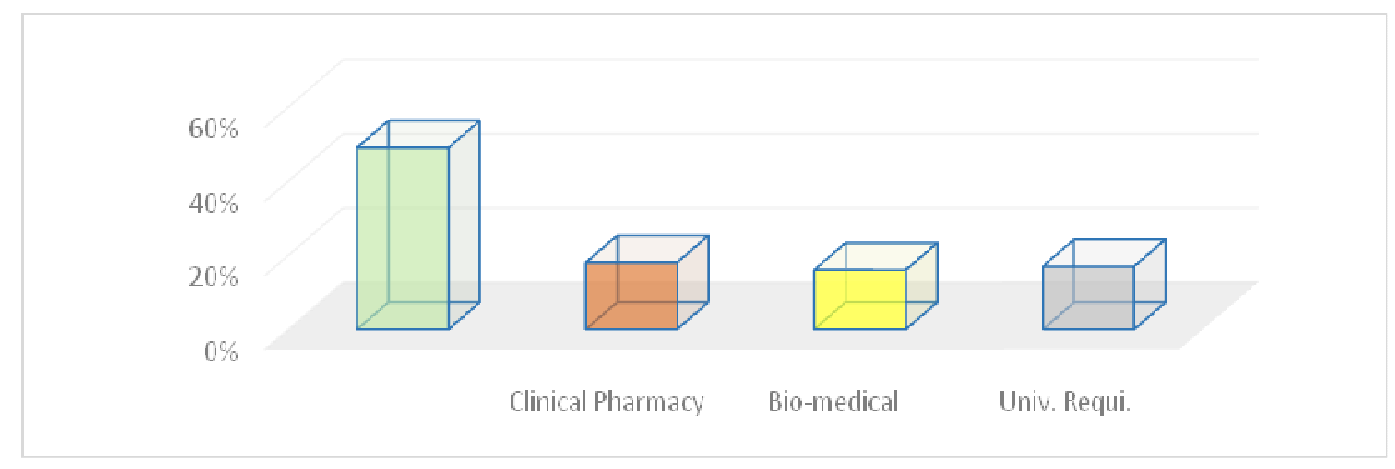

C-Universities from Africa

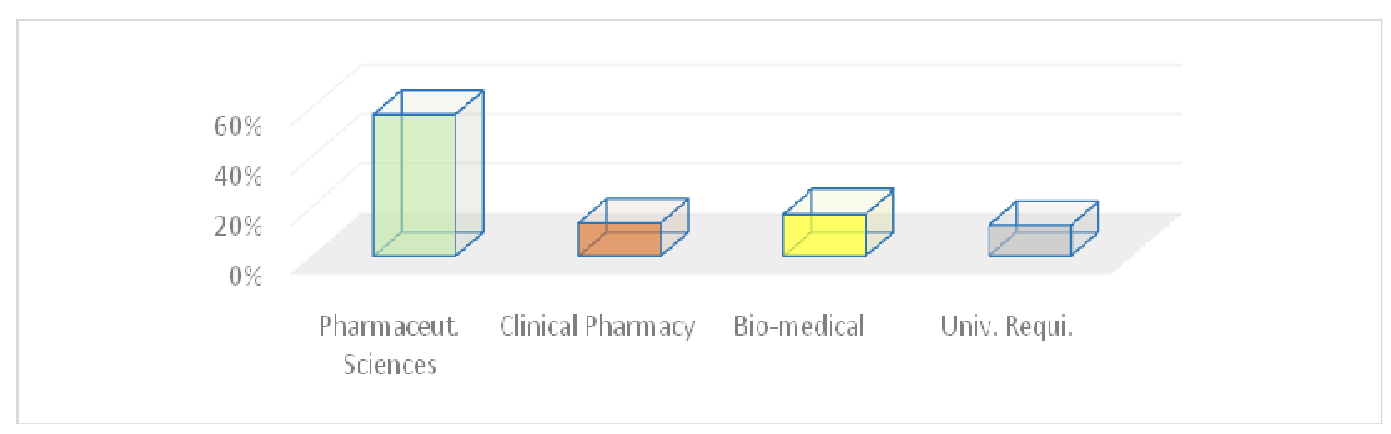

D-Universities from Asia 


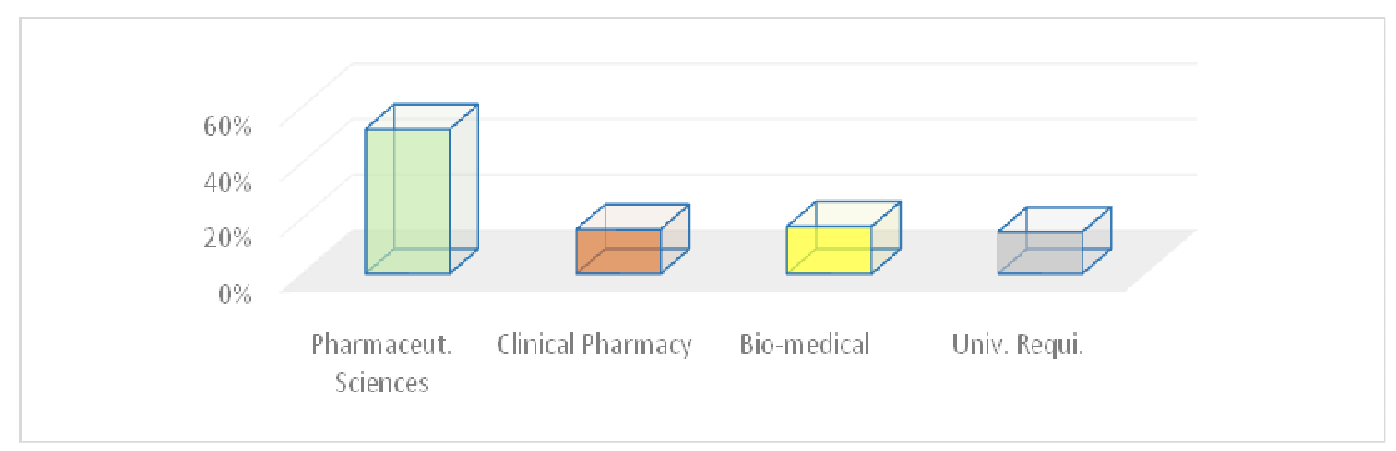

Fig. 1: Comparative credit hour structures of B. Pharm programs

Fig. 2 indicates that in UAE and other Gulf Universities, the credit hours allotted to Clinical Pharmacy are relatively high compared to
Pharmacognosy. Whereas in Asian Universities it is moderately high and in African Universities, it is nearly similar.

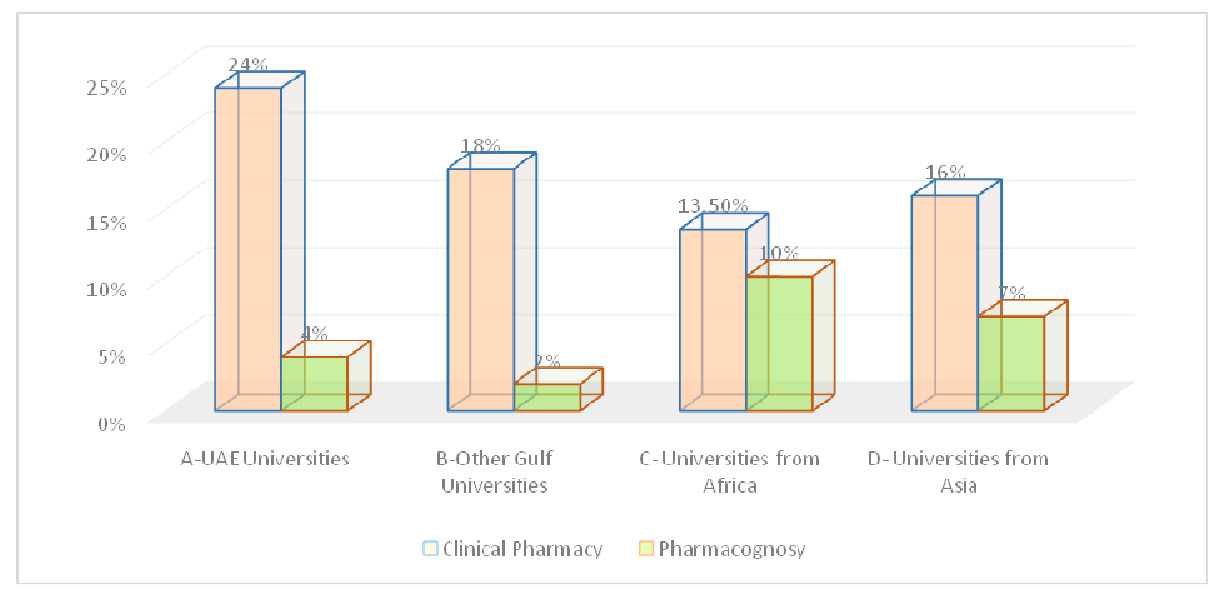

Fig. 2: Comparative credit hours of B. Pharm programs between pharmacognosy and clinical pharmacy courses

\section{DISCUSSION}

From above analysis of the results, we noticed that the credit hours allocated to Clinical Pharmacy Subject (18-24\%) in Gulf Universities, is relatively high as compared to the four Subjects of Pharmaceutical Courses (48-49\%) while credit hours allocated to Pharmacognosy range between $2-4 \%$. In African Universities, total Pharmaceutical Courses have $57 \%$ share in the total number of credit hours for the B. Pharm, of which Pharmacognosy has 10\% share; Clinical Pharmacy Courses have $13.5 \%$, which show nearly even distribution between the Pharmacy Subjects. Some developing countries such as Sudan (University of Khartoum), Egypt (Cairo University), University of Nigeria and Syria (Al-Baath University) maintain such a balance. In Asian Universities, total Pharmaceutical Courses have 52\% share in the total credit hours for the B. Pharm course of which Pharmacognosy has $7 \%$ share; Clinical Pharmacy Courses have $16 \%$ share in the total credit hours, showing somehow moderate distribution, though Pharmacognosy is relatively low. Jordan University tend to adopt syllabi similar to Gulf Universities and relatively different from other Asian universities such as universities in Turkey and Syria.

\section{CONCLUSION}

In Africa and Asia, Clinical Pharmacy is very limited in its application. Moreover, such countries need to develop their Pharmaceutical Industries, explore their natural resources of medicinal plants as raw materials for the Pharmaceutical Industry and increase the Community awareness for proper use of medicinal plants in Traditional Medicine. However, these issues require a knowledgeable Pharmacist in the field of Pharmaceutical Sciences including Pharmacognosy. Hence, the new trends in the total shift of Pharmacy Syllabi towards Clinical Pharmacy may not be practical, for the time being, in such countries. The change requires the involvement of not only Universities but also other Health care authorities and Regulatory bodies involved in Pharmacy Practice. In addition to the recognition of the new role of Pharmacist and availability of practice site in those countries.

What is required in these countries is a balanced curriculum that accommodates fundamentals of Clinical Pharmacy, the fundamentals of Pharmaceutical Sciences, in addition to gearing up their students towards the vital attitude of life-long learning or continuous professional development and proper training on evidence based practice. This should be in coordination with Health authorities and Regulatory bodies involved in Pharmacy Practice who decide the National needs of the country in the field of Pharmacy Services. Complementary Degrees such as PharmD and Master of Clinical Pharmacy or Industrial Pharmacy, designed according to the National needs can be beneficial. Adequate increase of total credit hours in some universities in order to cover fundamentals of pharmaceutical sciences and fundamentals of clinical pharmacy may also work.

\section{AUTHORS CONTRIBUTIONS}

All the author have contributed equally

\section{CONFLICT OF INTERESTS}

Declared none

\section{REFERENCES}

1. Bhagavathula AS, Sarkar BR, Patel I. Clinical pharmacy practice in developing countries: focus on India and Pakistan. Arch Pharm Practice 2014;5:91-4.

2. Mangasuli S, Rajan S, Khan SA. A decade of pharmacy practice education in India. Am J Pharm Educ 2008;72:16. 
3. Azhar S, Hassali MA, Ibrahim MI, Ahmed M, Masood I, Shafie AA. The role of pharmacist in developing countries: the current scenario in Pakistan. Human Resources Health 2009;7:54.

4. Kheir N. Pharmacy education and practice in 13 middle eastern countries. Am J Pharm Edu 2008;72:133.

5. Hussain A, Malik M, Abdullah S. Review of evolving trends in clinical pharmacy curriculum around the globe. Am J Pharmacol Sci 2017;5:1, 1-7.

6. Woster MP. NSAIDs: chemistry and pharmacological actions. Am J Pharm Edu 2003;67:1-7.

7. Brown B, Skau K, Wall A. Learning across the curriculum: connecting the pharmaceutical sciencesto practice in the first professional year. Am J Pharm Educ 2009;73:36.

8. Khan TM, Anwar M, Ahmed MKK. A perspective forclinical pharmacy curriculum development and validation in Asian developing nations. J Young Pharma 2011;3:151-4.

9. Khan TM. Critical consideration in pharmacy curriculum development in South Asian and Southeast Asian developing nations. Am J Pharm Educ 2010;74:176.

10. Faculty of Pharmacy at Ajman University. Available from: http://www.ajman.ac.ae/B-Pharm. [Last accessed on 05 Aug 2018]

11. Faculty of Pharmacy at Al Ain University of science and technology. Available from: https://aau.ac.ae/en/undergraduate-programs/ bsc-in-pharmacy. [Last accessed on 05 Aug 2018]

12. Faculty of Pharmacy at University of Sharjah. Available from: http://www.sharjah.ac.ae/en/academics/Colleges/Pharmacy/ Pages/default.aspx. [Last accessed on 05 Aug 2018]

13. Dubai Pharmacy College for Girls. Available from: https://www.dpc.edu/academics.php?category. [Last accessed on 05 Aug 2018]

14. RAK Medical and Health Sciences University. Available from: http://www.rakmhsu.com/pharmacy-college-in-dubai/studyplan/b-pharm/. [Last accessed on 05 Aug 2018]
15. Faculty of Pharmacy at Almaarefa University. Available from: https://mcst.edu.sa/en/e-pharmacy-study-pkan. [Last accessed on 05 Aug 2018]

16. Health Science Centre at Kuwait University. Available from: http://www.hsc.edu.kw. [Last accessed on 05 Aug 2018]

17. Faculty of Pharmacy at University of Bahrain. Available from: http://www.uob.edu.bh/en/index.php/academicprograms/bachelor. [Last accessed on 05 Aug 2018]

18. College of Pharmacy at Qatar University. Available from: http://www.qu.edu.qa/pharmacy/departments/programs/do ctor-of-pharmacy/study-plan. [Last accessed on 05 Aug 2018]

19. College of Pharmacy at Lebanese International University in Yemen. Available from: http://www.liuyemen.com/ Admissions/undergraduate-admissions.Php. [Last accessed on 05 Aug 2018].

20. Faculty of Pharmacy at University of Khartoum. Available from: http://pharm.uofk.edu/index.php/en/. [Last accessed on 05 Aug 2018]

21. Faculty of Pharmacy at Cairo University. Available from: https://www.pharma.cu.edu.eg/. [Last accessed on 05 Aug 2018]

22. Faculty of Pharmaceutical Sciences at University of Nigeria. Available from: http://pharmacy.unn.edu.ng/programmes/. [Last accessed on 05 Aug 2018]

23. Faculty of Pharmacy at Near East University. Available from: https://neu.edu.tr/academic/faculties/faculty-ofpharmacy/courses/undergraduate-courses/. [Last accessed on 10 Aug 2018]

24. Faculty of Pharmacy at $\mathrm{Al}$ baath University. Available from: http://pharmacy.albaath-univ.edu.sy/. [Last accessed on 15 Aug 2018]

25. Faculty of Pharmacy at JUST. Available from: http://www.just.edu.jo/FacultiesandDepartments/FacultyofPh armacy/. [Last accessed on 20 Aug 2018] 